\title{
ARTICLE OPEN Response of surface ozone over the continental United States to UV radiation declines from the expected recovery of stratospheric ozone
}

\author{
A. Hodzic ${ }^{1,2}$ and S. Madronich (iD)
}

The response of surface ozone concentrations to decreases in ultraviolet (UV) radiation that are expected from the recovery of stratospheric ozone by the end of the twenty-first century is examined with the regional WRF-Chem model. The study is performed over the continental United States for the summer of 2010 at $12 \mathrm{~km}$ horizontal resolution which, compared to previous studies, allows a better separation of chemical regimes that exhibit opposite responses to UV radiation changes. Our results show that on the regional scale, surface ozone is expected to increase by 0.5 to $1 \mathrm{ppb}$ due to its slower destruction, while the opposite can be seen in the vicinity of some urban centers where ozone concentrations could decrease by up to 1 ppb due to its slower photochemical production. Geographic overlay with population shows however a relatively small net increase in exposure of $\sim$ $0.4 \mathrm{ppb}$, with an asymmetric distribution characterized by some disbenefit to the majority of the US population and a benefit to a relatively small fraction ( 4\%) of population.

npj Climate and Atmospheric Science (2018)1:35; doi:10.1038/s41612-018-0045-5

\section{INTRODUCTION}

The transmission of ultraviolet (UV) radiation through the stratosphere is an important regulator of tropospheric chemistry. Ground-level ozone $\left(\mathrm{O}_{3}\right)$ is one product of this chemistry, formed when mixtures of nitrogen oxides $\left(\mathrm{NO}_{\mathrm{X}}\right)$ and volatile organic compounds (VOCs) are exposed to solar UV radiation. ${ }^{1,2}$ The health effects from exposure to ozone are widely recognized ${ }^{3,4}$ and have led to regulation that improved air quality in some locations, while other locations continue to show worsening conditions. ${ }^{5,6}$ Future concentrations of ground-level ozone will depend strongly on future changes in $\mathrm{VOC}$ and $\mathrm{NO}_{\mathrm{x}}$ emissions as well as temperature, as already suggested by numerous studies, ${ }^{7,8}$ but the effects of changes in UV radiation caused by stratospheric ozone recovery must also be quantified and superimposed.

Stratospheric ozone in recent years (2008-2012) has been lower than preindustrial (1964-1980) values by several percent at midlatitudes of both hemispheres, but full recovery is expected by the middle of this century and may reach even higher values (superrecovery) due to interactions with changing concentrations of greenhouse gases. ${ }^{9}$ Associated with this recovery, lower levels of tropospheric UV radiation are expected. ${ }^{10}$ Changes in UV radiation will in turn influence future surface ozone concentrations. Liu and Trainer $^{11}$ noted that both production and loss of tropospheric ozone increase when UV radiation is increased, using a relatively simple box model. Thompson et al. ${ }^{12}$ used a one-dimensional model to reach qualitatively similar conclusions. More recently, a global modeling study by Zhang et al. ${ }^{13}$ found that the UV decline upon recovery of stratospheric ozone to 1980 levels would lead to ubiquitous increases in ground-level ozone, of magnitudes that are not negligible in the context of understanding future background tropospheric ozone. They predicted an increase in summer time surface ozone concentrations by up to $0.25 \mathrm{ppb}$ throughout the United States with the maximum increase found over the northwest. However, the spatial resolution of their model, $4 \times 5$ degrees, may be too coarse to discern changes at urban scales where much of the ozone production occurs.

\section{RESULTS AND DISCUSSION}

Here, we use the regional Weather Research and Forecasting with Chemistry (WRF-Chem) model with horizontal grid spacing of $12 \mathrm{~km}$ to examine the likely implications on air quality for the future stratospheric ozone recovery over the contiguous United States (CONUS), between current (average 2001-2011) and the end of the twenty-first century levels (average 2075-2095). Stratospheric ozone concentrations were taken from the simulations of the National Center for Atmospheric Research (NCAR) whole atmosphere community climate model (WACCM) that were performed for the Chemistry-Climate Model Initiative $\left(\mathrm{CCMI}^{14}\right)$. For the current day conditions, we used averaged stratospheric ozone concentrations for 2001-2011, and for the future "stratospheric ozone recovery" conditions, we averaged model outputs for 2075-2095. The expected increase in the stratospheric ozone column associated with the ozone recovery is shown in Fig. 1 for the summer months (June-August). It varies somewhat with latitude, and ranges from 4 to $5 \%$ at $25-35^{\circ} \mathrm{N}$, and from 5 to $6.5 \%$ at $35-50^{\circ} \mathrm{N}$.

\footnotetext{
${ }^{1}$ Atmospheric Chemistry Observations and Modeling Laboratory, National Center for Atmospheric Research, Boulder, CO, USA and ${ }^{2}$ Laboratoire d'Aérologie Université de Toulouse, CNRS, UPS, Toulouse, France

Correspondence: A Hodzic (alma@ucar.edu)
}

Received: 4 April 2018 Revised: 23 August 2018 Accepted: 30 August 2018

Published online: 04 October 2018 

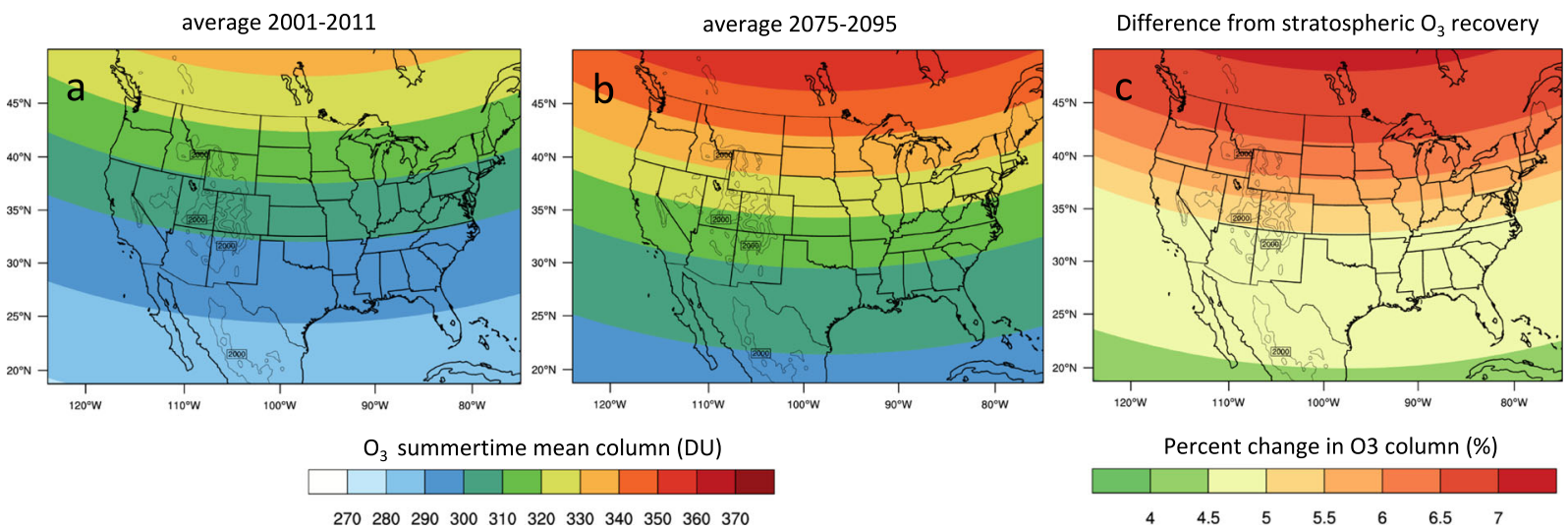

Fig. 1 Ozone column as predicted by the WACCM model for the summer months (June-August) for the current 2001-2011 period (left plot) and future 2075-2095 period (middle plot). The predicted percent increase in stratospheric ozone column due to expected ozone recovery is also shown (right plot)

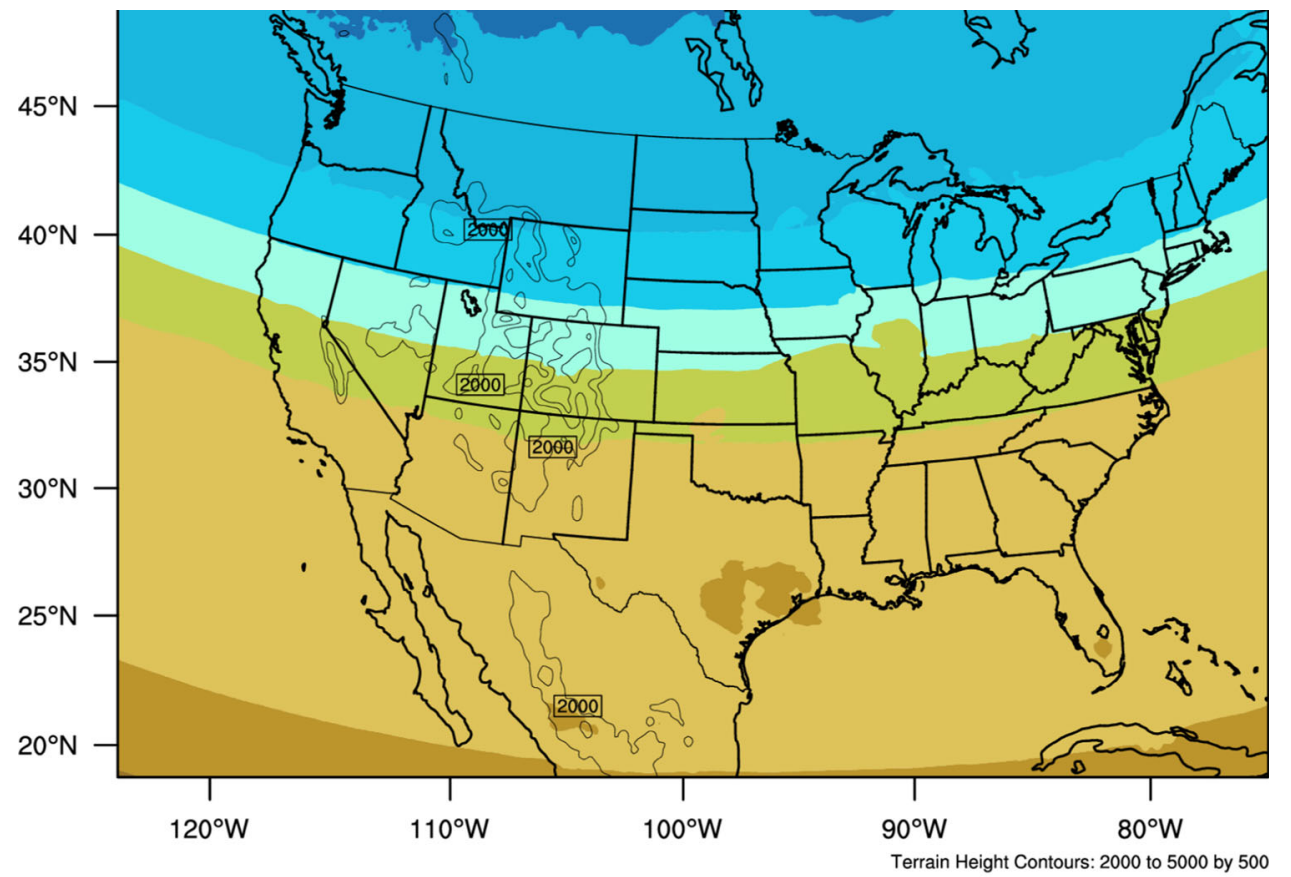

Change in the UV Index (\%)

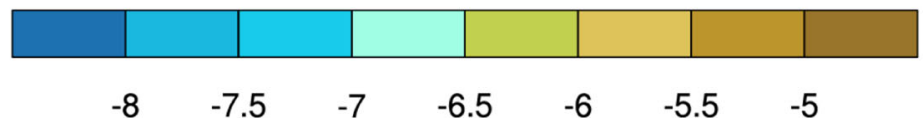

Fig. 2 The percentage difference in the early afternoon mean UV index between the control and stratospheric recovery model runs. Zonal inhomogeneity of the changes is due to slight differences in cloud cover between the two simulations

An effect of stratospheric ozone recovery on human health is typically estimated through the ultraviolet index (UVI) which quantifies the potential for damage to the skin and eyes associated with UV radiation received at the surface. Figure 2 shows the change in the early afternoon (20-24 Universal Time Coordinated (UTC)) surface UVI which decreases by 5 to $8 \%$ over the CONUS with a strong gradient between $20^{\circ} \mathrm{N}$ and $50^{\circ} \mathrm{N}$. The UVI was calculated by multiplying by 40 the erythemal irradiance that is predicted by the WRF-Chem model following McKinlay and Diffey. $^{15}$

The focus of our study is estimating the effect of changes in UV photolysis on $\mathrm{O}_{3}$ formation at the surface. The UV photolysis of $\mathrm{O}_{3}$ gives excited oxygen atoms $O\left({ }^{1} D\right)$, followed by reaction of these with water $\left(\mathrm{H}_{2} \mathrm{O}\right)$,

$\mathrm{O}_{3}+\mathrm{h} \nu(\lambda<330 \mathrm{~nm}) \rightarrow \mathrm{O}_{2}+\mathrm{O}\left({ }^{1} \mathrm{D}\right) \quad \mathrm{J}(\mathrm{O} 1 \mathrm{D})$,

$\mathrm{O}\left({ }^{1} \mathrm{D}\right)+\mathrm{H}_{2} \mathrm{O} \rightarrow \mathrm{OH}+\mathrm{OH}$,

Net : $\mathrm{O}_{3}+\mathrm{h} \nu(\lambda<330 \mathrm{~nm})+\mathrm{H}_{2} \mathrm{O} \rightarrow \mathrm{O}_{2}+\mathrm{OH}+\mathrm{OH}$.

The net reaction $\mathrm{R} 1$ is a direct loss of $\mathrm{O}_{3}$, but the $\mathrm{OH}$ radicals produced in $\mathrm{R} 1 \mathrm{~b}$ can also initiate a sequence of reactions that generates $\mathrm{O}_{3}$ if nitrogen oxides $\left(\mathrm{NO}_{\mathrm{x}}\right)$ are present. This is illustrated with carbon monoxide,

$\mathrm{OH}+\mathrm{CO}\left(+\mathrm{O}_{2}\right) \rightarrow \mathrm{CO}_{2}+\mathrm{HOO}$ 

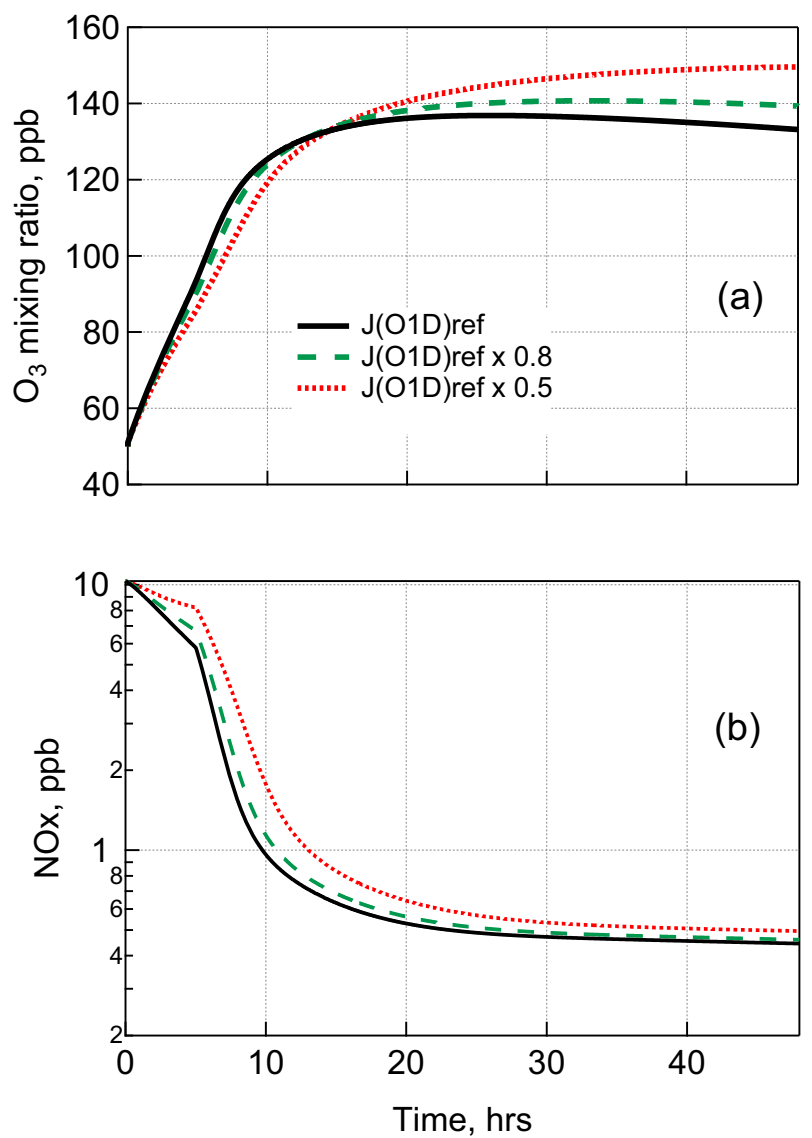

Fig. 3 a Illustrative evolution of ground-level ozone concentration before (solid, black) and after a 20\% (dashed, green) and 50\% reduction in J(O1D), the photolysis coefficient for reaction $\mathrm{O}_{3}+\mathrm{hv}$ $\left(+\mathrm{H}_{2} \mathrm{O}\right) \rightarrow 2 \mathrm{OH}+\mathrm{O}_{2}$ (R1). b Concentration of nitrogen oxides $\left(\mathrm{NO}_{x}\right.$ $=\mathrm{NO}+\mathrm{NO}_{2}$ ); note that when $\mathrm{NO}_{x}$ falls below ca. $0.5-1 \mathrm{ppb}$, the sensitivity of $\mathrm{O}_{3}$ to $\mathrm{J}(\mathrm{O} 1 \mathrm{D})$ changes sign. Chemical evolution generated using a box model with the full MOZART gas-phase chemical mechanism ${ }^{16}$ used in WRF-Chem (see Methods). The simulation is initialized using WRF-Chem for a typical Chicago grid cell with urban emissions for the first $5 \mathrm{~h}$, then ran in a Lagrangian mode without emissions for several days

where the peroxy radicals, $\mathrm{HOO}$ (and their organic analogs), can react with nitric oxide (NO) to generate nitrogen dioxide $\left(\mathrm{NO}_{2}\right)$ which is easily photolyzed to make $\mathrm{O}_{3}$ :

$\mathrm{HOO}+\mathrm{NO} \rightarrow \mathrm{OH}+\mathrm{NO}_{2}$,

$\mathrm{NO}_{2}+\mathrm{h} \nu(\lambda<420 \mathrm{~nm})\left(+\mathrm{O}_{2}\right) \rightarrow \mathrm{NO}+\mathrm{O}_{3}$

Decreases in the rate coefficient of R1a (due to UV decreases associated with stratospheric $\mathrm{O}_{3}$ recovery) therefore slow both production (via R4) and loss (via R1) of surface $\mathrm{O}_{3}$, the net being sensitive to the availability of $\mathrm{NO}_{x}$. VOCs can also contribute to $\mathrm{O}_{3}$ formation and destruction, in analogy with the simple CO oxidation (R2), but typically with greater complexity including branched pathways, metastable intermediates and reservoir species, and radical chain termination reactions. Figure 3 shows the response of the chemical mechanism used here (see Methods) to reductions in J(O1D), for an air parcel initialized with urban conditions (high $\mathrm{NO}_{x}$ ) and allowed to evolve for several days. Reductions in J(O1D) cause lower $\mathrm{O}_{3}$ initially (Fig. 3a), but with a crossover to higher values at longer time scales. The lower panel (Fig. $3 \mathrm{~b}$ ) shows that $\mathrm{NO}_{\mathrm{x}}$ values are in the range $0.5-1.0 \mathrm{ppb}$ when the $\mathrm{O}_{3}$ sensitivity to J(O1D) changes sign.
The transition from $\mathrm{O}_{3}$ production to $\mathrm{O}_{3}$ destruction depends sensitively on the chemical and physical environment, including $\mathrm{NO}_{x}$ and $\mathrm{CO}$ (or hydrocarbons) concentrations, relative humidity, temperature, as well as UV irradiation. While the simplified mechanism (R1-R4) and Fig. 3 serve to illustrate the chemical concepts underlying this transition, accurate quantification over a specific region and time (e.g., summer time United States) requires a full chemistry-transport model including realistic emissions, transport and transformations, and deposition. Notably, while only two photolysis reactions ( $\mathrm{R} 1 \mathrm{a}$ and $\mathrm{R} 4$, with only the former being sensitive to stratospheric $\mathrm{O}_{3}$ ) were discussed above, the WRF-Chem simulations include the effect of stratospheric ozone change on all photo-labile molecules (e.g., peroxides, carbonyls, nitrates) included in the MOZART ${ }^{16}$ chemical mechanism.

The response of the surface ozone photolysis coefficient J(O1D) to small changes in the overhead $\mathrm{O}_{3}$ column can be seen from the normalized (logarithmic) sensitivity coefficient, defined as

$a=\frac{\partial \log [J(O 1 D)]}{\partial \log (\text { column_O3 })} \approx \frac{[\Delta J(O 1 D) / J(O 1 D)]}{\left[\Delta \text { Column_O} O_{3} / \text { Column_O } O_{3}\right]}$,

where column $\mathrm{O}_{3}$ and J(O1D) are calculated for the current levels of stratospheric ozone, while $\Delta$ Column_ $\mathrm{O}_{3}$ and $\Delta \mathrm{J}(\mathrm{O} 1 \mathrm{D})$ represent the difference between the recovered and current levels. Thus, $a$ is the percentage change in J(O1D) resulting from a percent change in total ozone column.

The calculated sensitivity for J(O1D) is shown in Fig. 4 for the afternoon-averaged values, and ranges from -1.4 in the southern United States to -1.55 in the northern United States. These values are generally in good agreement with previous estimates (see, e.g., refs. ${ }^{17-20}$ ), with earlier studies ca. 0.2 higher in absolute value (more sensitive) until recognition of the substantial UV-A tail in $O\left({ }^{1} D\right)$ quantum yields. ${ }^{21}$ The sensitivity depends slightly on the slant ozone column, ${ }^{22}$ which is evident in Fig. 4, both as a latitudinal dependence and as a (small) longitudinal variation resulting from time-averaging over the 20:00-24:00 UT window (sampling slightly different ranges of solar zenith angles). Thus, with a in the range -1.40 to -1.55 , relative decreases in J(O1D) are about $40-55 \%$ larger than the increases in the stratospheric ozone, and the corresponding decrease in J(O1D) ranges from 6 to $10 \%$ over the CONUS, with the largest perturbations found over the northern part of the domain. The sensitivities for other photolysis reactions are generally smaller, about $-0.05,-(0.2-0.5)$, and -0.3 for $\mathrm{NO}_{2}$, $\mathrm{CH}_{2} \mathrm{O}$, and $\mathrm{H}_{2} \mathrm{O}_{2}$, respectively (see Table 2 of McKenzie et al. ${ }^{20}$ ). Changes in these photolysis coefficients were included within the model, but because of these lower sensitivities they were of minor importance relative to the changes in J(O1D).

Figure $5 \mathrm{~b}$ shows the change in ground-level ozone concentrations over CONUS resulting from the recovery of stratospheric ozone by the end of the century, via the decrease in tropospheric photolysis frequencies (primarily R1). Both positive and negative responses can be seen, with a general prevalence of increased ozone concentrations over most regions, as already found by Zhang et al. ${ }^{13}$, but also with improved air quality in the vicinity of some large urban centers. The increase in the regional ozone levels ranges from $0.2 \mathrm{ppb}$ over north and northwest United States, to $\sim 0.5$ over central United States and northern Mexico, and up to $1 \mathrm{ppb}$ over the southeast United States and off the east coast. This is consistent with the fact that stratospheric ozone recovery would decrease the photochemical ozone destruction rates leading to a higher regional ozone background. This increase in regional ozone concentrations is also consistent with the previously discussed box model results (Fig. 3). The decrease in surface ozone over urban areas of $0.5-1 \mathrm{ppb}$ can clearly be seen over California, in and downwind of Los Angeles and San Francisco, as well as over the Great Lakes downwind of Chicago and Detroit. Smaller ozone reductions are expected for other 


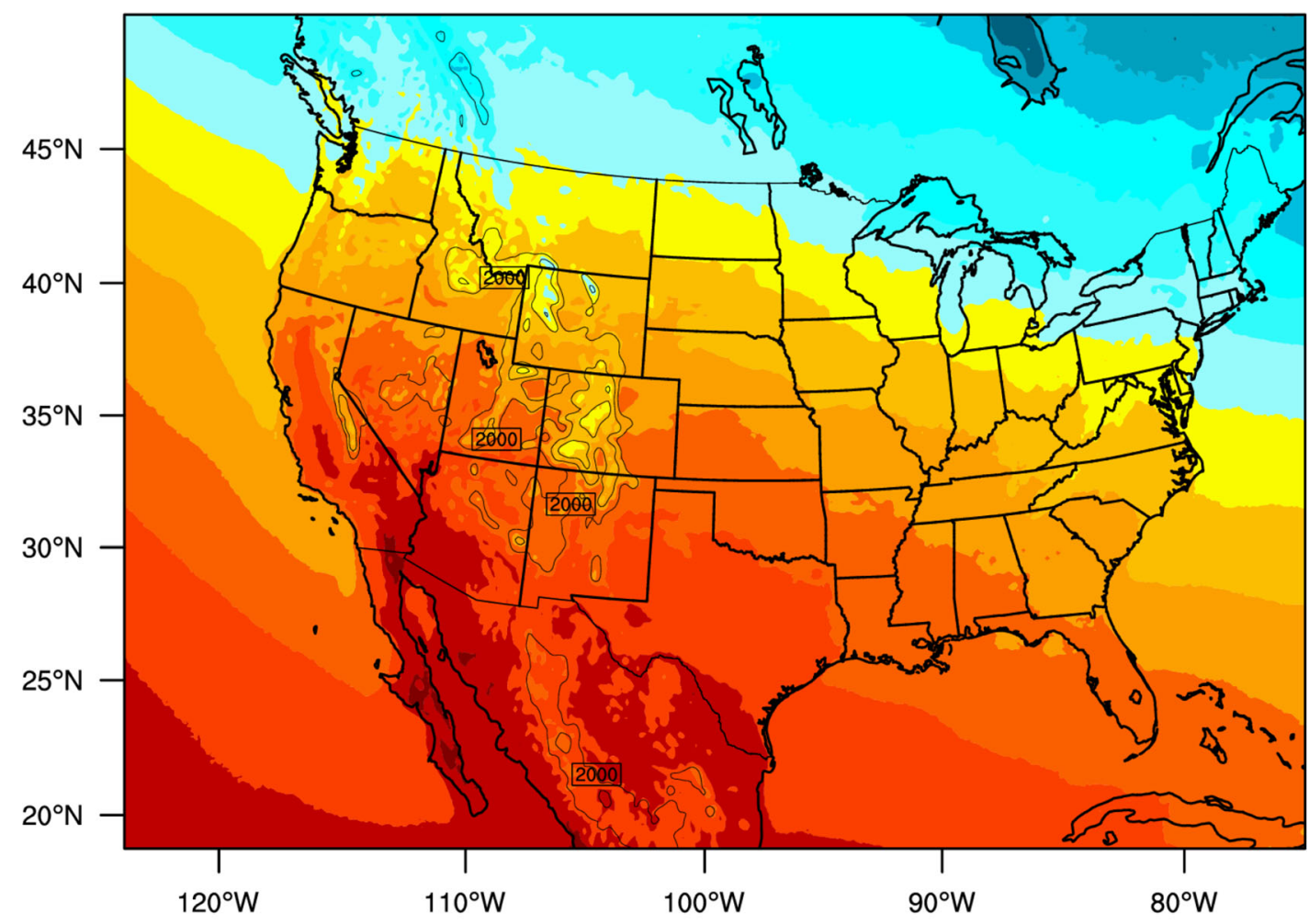

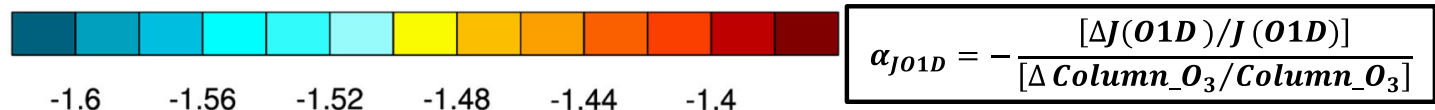

Fig. 4 Sensitivity of surface ozone photolysis rates to the increase in the stratospheric ozone column as predicted by the $12 \mathrm{~km}$ WRF-Chem simulation for the summer 2010. The sensitivity is calculated between current 2001-2011 and future 2075-2095 stratospheric ozone levels

urban areas including Miami, Houston, Denver, New York, and Boston. These negative changes are found in high- $\mathrm{NO}_{x}$ urban regions where ozone production rates are the strongest, and where the stratospheric ozone recovery would decrease the photochemical ozone production rates as illustrated by the box model results in Fig. 3. This decrease in ozone was not seen by Zhang et al. ${ }^{13}$ probably due to insufficient horizontal resolution $\left(4^{\circ} \times 5^{\circ}\right)$ of their simulations to represent gradients in nitrogen oxides which strongly influence ozone chemistry. Figure 6a shows the distribution of average ground-level ozone (solid) and the change (hatched) upon recovery of the stratosphere. About $60 \%$ of the model grid points will undergo an increase in ozone between 0 and $0.5 \mathrm{ppb}$, while $\sim 35 \%$ will experience a larger increase of $0.5-2 \mathrm{ppb}$. Only $\sim 2 \%$ of grid points will experience a ground-level ozone reduction from stratospheric $\mathrm{O}_{3}$ recovery.

To qualitatively assess the potential effect of the stratospheric ozone recovery on population exposure, the model ozone predictions were combined with gridded population data for 2005 (http://sedac.ciesin.columbia.edu). Figure 5d shows the change in surface ozone concentrations weighted by population density (with units normalized to the total population). This clearly shows the importance of ozone changes occurring in the most densely populated regions. A spatial contrast can be noted between the cities of the west coast that will experience a slight improvement in air quality and the cities located in the eastern parts of the country that will experience a degradation in air quality with the stratospheric ozone recovery, with the exception of some limited areas of Chicago, Denver, New York, Miami, and St. Paul.
Figure $6 \mathrm{~b}$ estimates the number of people in the United States who will be affected by a given change in ground-level ozone upon recovery of the stratosphere. A majority of the population will be exposed to higher levels of ozone, with 175 million people who will experience an increase of $0.5-1 \mathrm{ppb}$ in ozone, and $\sim 35$ million who will experience increases exceeding $1 \mathrm{ppb}$. About 10 million people will benefit from a decrease in ozone concentrations by up to $1 \mathrm{ppb}$. The CONUS-wide average for the stratospheric ozone recovery is $\sim 1 \%$ more ground-level ozone, and $0.4 \%$ more population-weighted ozone.

The calculations were repeated at $36 \mathrm{~km}$ model horizontal resolution and the results (see Fig. SI- 1 and SI-2) are comparable within $10 \%$ to those obtained at $12 \mathrm{~km}$ resolution. In the coarse model simulation, the increase in surface $\mathrm{O}_{3}$ caused by the recovery of stratospheric ozone is $\sim 5-10 \%$ larger over the southeast United States than in the $12 \mathrm{~km}$ simulation, i.e., second order on the UV-induced changes. In addition, urban reactivity is often $\mathrm{NO}_{x}$ saturated so the $\mathrm{NO}_{x}$ lifetime is moderately long, while in coarse resolution simulations the high local $\mathrm{NO}_{x}$ concentrations are immediately diluted, increasing the reactivity $(\mathrm{OH})$ and the rate of $\mathrm{NO}_{\mathrm{X}}$ removal (by $\mathrm{OH}+\mathrm{NO}_{2} \rightarrow \mathrm{HNO}_{3}$ ). Hence, coarse resolution simulations have less $\mathrm{NO}_{X}$ (and more $\mathrm{HNO}_{3}$ ). This faster decrease in $\mathrm{NO}_{X}$ in coarse compared to fine simulations results in a faster change in sign in $\mathrm{O}_{3}$ production, and in stronger $\mathrm{O}_{3}$ net destruction rates (as seen in Fig. $5 \mathrm{~d}$ and $\mathrm{SI}-1 \mathrm{~d}$ ).

The overall similarity of the results also suggests that no further numerical benefits are to be obtained by modeling with even higher resolution. Previous studies (see, e.g., refs. ${ }^{23,24}$ ) have shown that the increase in spatial resolution from $36 \mathrm{~km}$ to $12 \mathrm{~km}$ provides a substantial improvement in the calculation of 


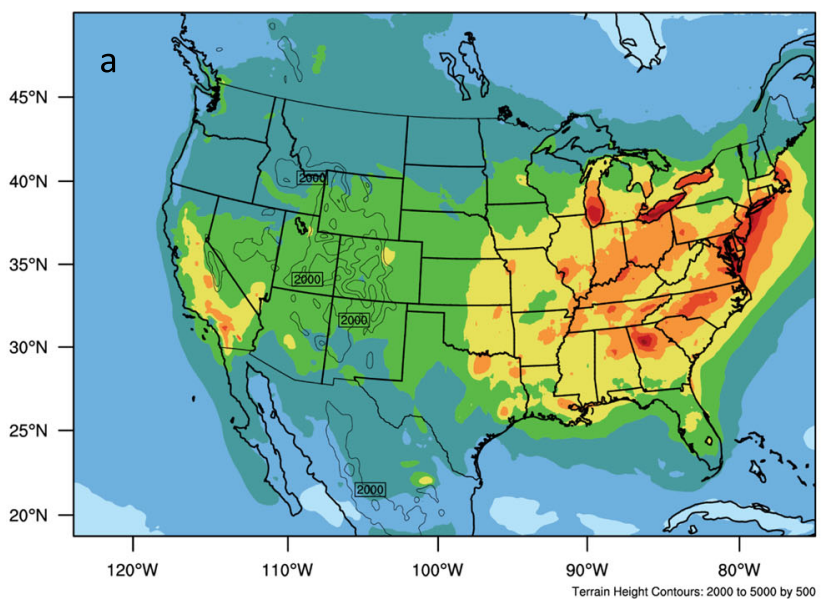

Surface $\mathrm{O}_{3}$ (ppbv)
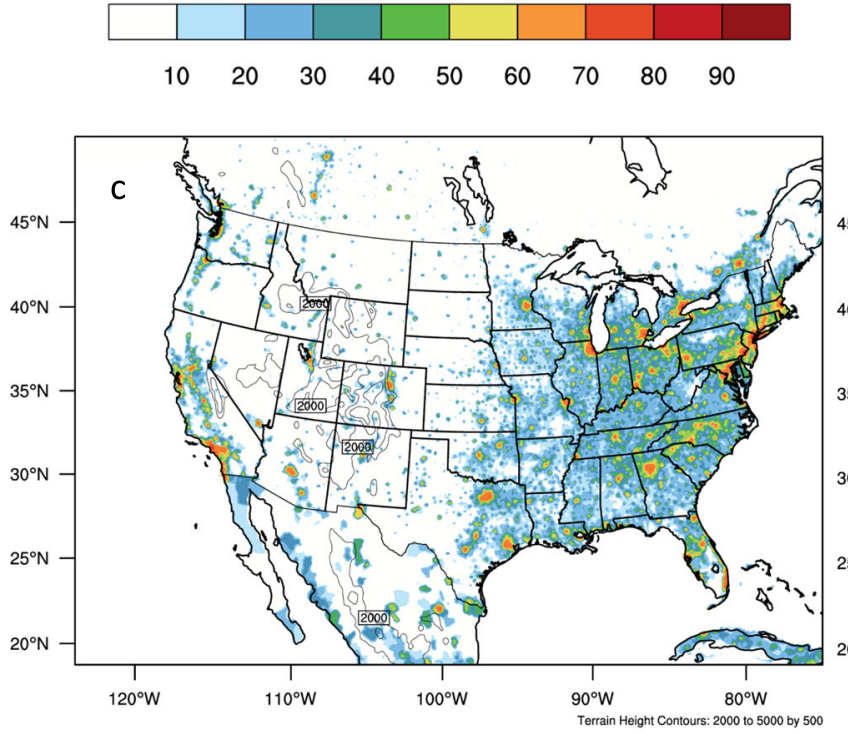

$\mathrm{O}_{3}$ exposure (ppt $\mathrm{x}$ population_fraction)

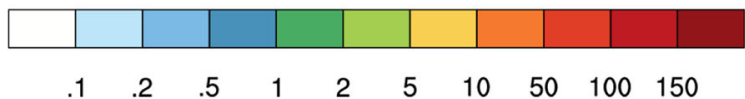

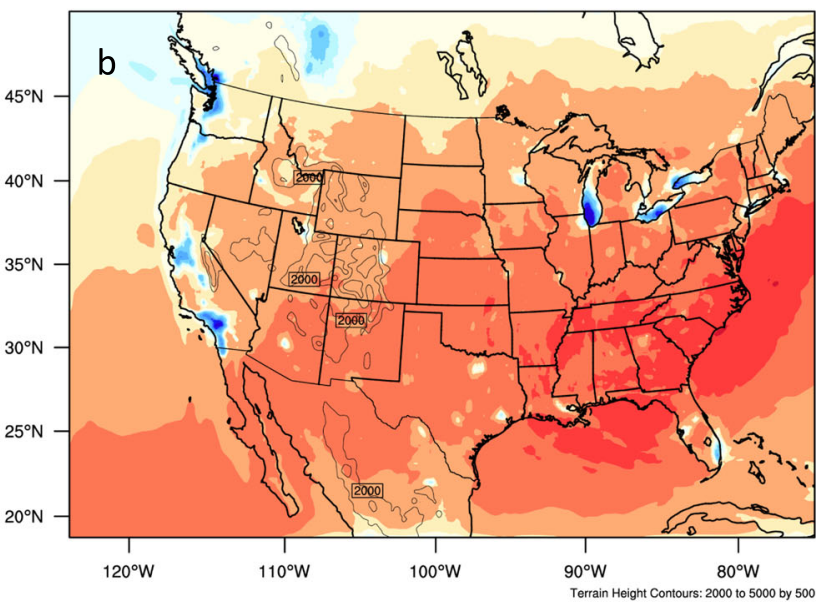

Change in surface $\mathrm{O}_{3}$ (ppbv)

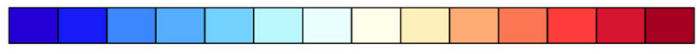

$\begin{array}{llllllllllllllll}-1 & -.8 & -.6 & -.4 & -.2 & -.1 & 0 & .1 & .2 & .4 & .6 & .8 & 1\end{array}$

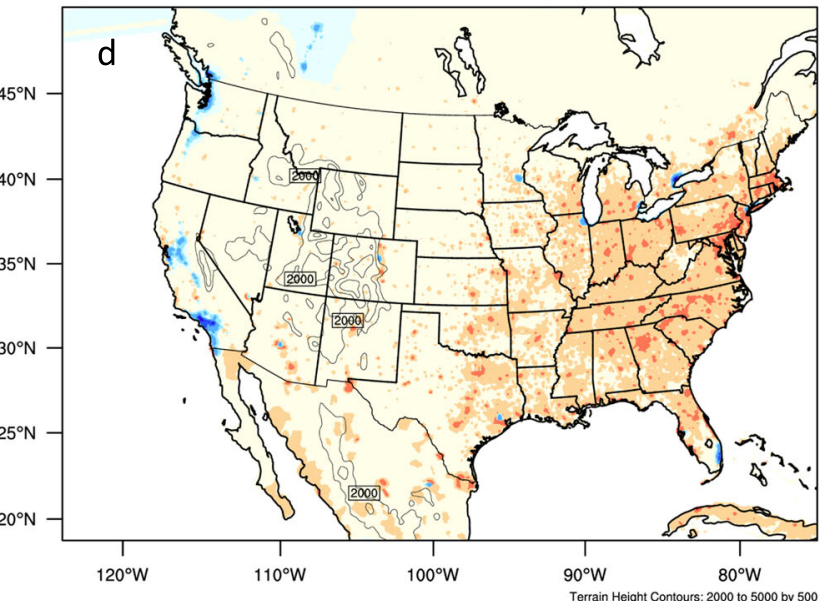

Change in $\mathrm{O}_{3}$ exposure (ppt x population_fraction)

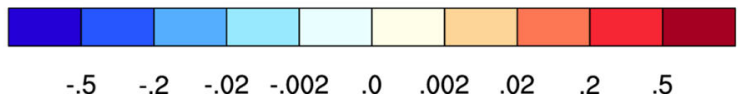

Fig. 5 Afternoon-averaged (20 to 24 UTC) summer time (June-August 2010) predictions of a surface ozone concentrations (ppb) and c population-scaled surface ozone (ppb times number of people) as predicted by the $12 \mathrm{~km}$ WRF-Chem model control run. The changes in response to stratospheric ozone recovery are shown for $\mathbf{b}$ surface ozone concentrations and $\mathbf{d}$ population scaled surface ozone

dynamical parameters and pollutant concentrations in urban areas, and that benefits of further resolution refinements are more limited.

In this study, we show that the expected stratospheric ozone recovery by the end of the twenty-first century and the subsequent decrease in UV radiation will lead to $5-10 \%$ decreases in the surface photolysis rates of tropospheric ozone. As a consequence, our results show that the response of the surface ozone to the stratospheric recovery is somewhat contrasting between the regional background and some urban centers, which could not be discerned in earlier coarser resolution study by Zhang et al. ${ }^{13}$. While an overall increase in surface ozone by 0.5 to $1 \mathrm{ppb}$ is expected due to its slower destruction on the regional scale, the opposite was found in and downwind of cities of the west coast where ozone concentrations could decrease by up to $1 \mathrm{ppb}$ due to its slower photochemical production. However, the population-weighted ozone changes indicate that a relatively small net increase in exposure of $\sim 0.4 \mathrm{ppb}$ is expected.

A majority of the population will be exposed to slightly higher levels of ozone, with $\sim 210$ million people experiencing an increase in ozone in the $0.5-1.5 \mathrm{ppb}$ range, while a relatively small fraction of the population ( 10 million people) will benefit from a decrease in ozone concentrations by up to $1 \mathrm{ppb}$.

The recovery of stratospheric ozone may change ground-level ozone by other processes, e.g., stratosphere-troposphere exchange of ozone, ${ }^{25}$ that are not directly related to UV radiation. It should be noted that emissions of isoprene which is one of the ozone precursors depend on visible radiation, ${ }^{26}$ but a direct dependence of isoprene emissions on UV radiation is not included in our model because it is not supported by the few relevant experimental studies. ${ }^{27-29}$ Factors other than stratospheric ozone may also be responsible for changes in UV radiation, e.g., clouds and aerosols. Therefore, our results are not projections, but rather 
$\left[\mathrm{O}_{3}, \mathrm{ppb}\right]$ at the surface

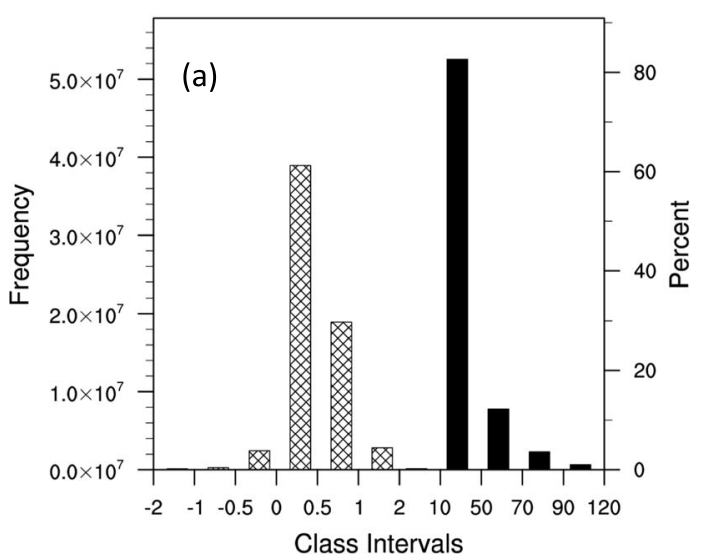

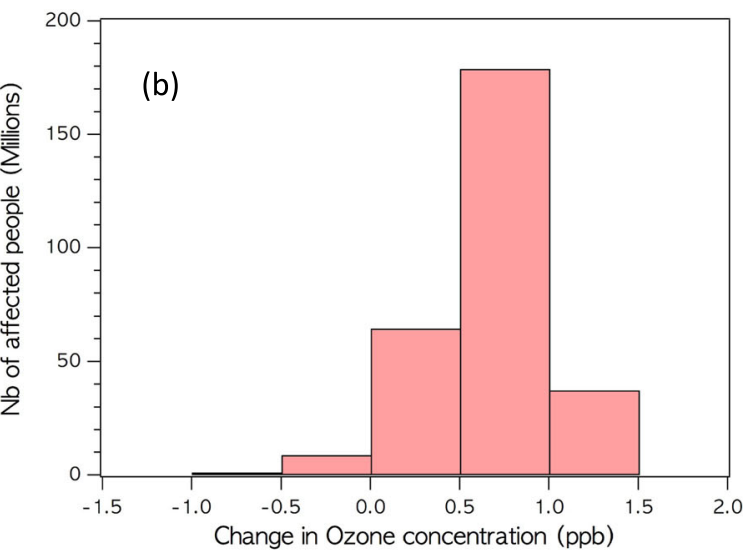

Fig. 6 a Frequency distribution of the afternoon (20-24 UTC) surface ozone concentrations (ppb) in the control run (solid bars), and changes in the distribution due to stratospheric ozone recovery (hatched bars) over the summer of 2010. $\mathbf{b}$ The number of affected people exposed to a given change in surface ozone

only quantify the UV-dependent component which then can be considered separately or superimposed.

The net UV-induced changes found for the contiguous United States are relatively small, even on the regional scale where $\mathrm{O}_{3}$ is already a well-known stressor of agriculture ${ }^{30}$ and further increases in its regional background would seem undesirable. Given that both the sign and the magnitude of surface $\mathrm{O}_{3}$ change are sensitive to the physical and chemical environment, it may be interesting to contrast the US situation to other regions that have substantially different chemical environments (especially with respect to $\mathrm{NO}_{\mathrm{x}}$ levels), such as East Asia or Europe.

\section{METHODS}

The simulations were performed using the WRF-Chem (version 3.6.1) at $12 \mathrm{~km}$ horizontal grid resolution over CONUS for the summer time period of June to August 2010. Meteorological initial and boundary conditions were obtained from the National Centers for Environmental Prediction (NCEP) analysis. The chosen WRF physical parameterizations include the RRTMG long-wave radiation, ${ }^{31}$ Mellor-Yamada-Janjic boundary layer, ${ }^{32}$ Noah land surface model, ${ }^{33}$ the Morrison et al. $^{34}$ double-moment microphysics scheme, and the Grell and Freitas $^{35}$ cumulus parameterization.

The chemistry setup uses a similar configuration to that of the Air Quality Model Evaluation International Initiative model intercomparison (AQMEII) project, ${ }^{36}$ which includes: (i) the MOZART gas-phase mechanism and the MOSAIC aerosol module as described by Knote et al. ${ }^{16}$, (ii) initial and boundary conditions based on the IFS-MOZART global chemistry model, and (iii) anthropogenic emissions of trace gases and aerosols as provided by the phase 2 of the AQMEII project and based on the modified 2008 National Emission Inventory (NEI). Specific for this study, we used biogenic emissions from the online MEGANv2.04 model ${ }^{26}$ with isoprene emissions over the southeast United States reduced by $25 \%$ as suggested recently by Canty et al. ${ }^{37}$. Photolysis rates were calculated online using the recently updated photolysis calculations in WRF-Chem based on the Tropospheric Ultraviolet Visible (TUV) model calculations as used by Ryu et al. $^{38}$. Effects of clouds on photolysis rates were included. To isolate the potential impact of stratospheric ozone recovery on photolysis rates from other effects such as changes in aerosol formation, aerosol effects on photolysis rates were not considered in this study.

Two sets of WRF-Chem model simulations were performed at $12 \mathrm{~km}$ grid resolution to quantify the effect of the stratospheric ozone recovery on the surface ozone concentrations and population exposure. The first set of simulations was performed using the present time stratospheric ozone, while the second set was performed using the future stratospheric ozone levels. Additional simulations were performed at a coarser horizontal resolution of $36 \mathrm{~km}$ for both present and recovered stratospheric ozone levels to test the sensitivity of the results to model resolution.

The control simulation has been compared with the U.S. Environmental Protection Agency (EPA) ground measurements for urban and rural sites for the summer of 2010 as shown in Fig. SI-3, and the results suggest that the model captures relatively well the distribution of the ozone daily maxima, with the tendency to overestimate the high ozone values as already reported in earlier studies. ${ }^{38,39}$

\section{DATA AVAILABILITY}

All model output data can be obtained from the authors upon request to alma@ucar. edu.

\section{ACKNOWLEDGEMENTS}

The authors acknowledge Dr. Douglas Kinnison (NCAR) for providing the stratospheric ozone concentrations from the WACCM model simulations. This research was supported by the National Center for Atmospheric Research, which is operated by the University Corporation for Atmospheric Research on behalf of the National Science Foundation. We would like to acknowledge high-performance computing support from Yellowstone provided by the Computational and Information Systems Laboratory of NCAR. A.H. was also supported by NASA NNX15AE38G.

\section{AUTHOR CONTRIBUTIONS}

A.H. performed the 3D model simulations and analysis. S.M. performed box model simulations and analysis. Both authors wrote the manuscript and discussed the results.

\section{ADDITIONAL INFORMATION}

Supplementary information accompanies the paper on the npj Climate and Atmospheric Science website (https://doi.org/10.1038/s41612-018-0045-5).

Competing interests: The authors declare no competing interests.

Publisher's note: Springer Nature remains neutral with regard to jurisdictional claims in published maps and institutional affiliations.

\section{REFERENCES}

1. Haagen-Smit, A. J., Bradley, C. E. \& Fox, M. M. Ozone formation in photochemical oxidation of organic substances. Indust. Eng. Chem. Res. 45, 2086-2089 (1953).

2. Finlayson-Pitts, B. J. \& Pitts, J. N. Jr. Chemistry of the Upper and Lower Atmosphere (Academic Press, New York, 2000).

3. EPA. Air Quality Criteria for Ozone and Related Photochemical Oxidants, Vol. 1 (U. S. Environmental Protection Agency, EPA, Research Triangle Park, 2006).

4. Lim, S. S. et al. A comparative risk assessment of burden of disease and injury attributable to 67 risk factors and risk factor clusters in 21 regions, 1990-2010: a systematic analysis for the Global Burden of Disease Study 2010. Lancet 380, 2224-2260 (2012). 
5. Parrish, D. D., Singh, H. B., Molina, L. \& Madronich, S. Air quality progress in North American megacities: a review. Atmos. Environ. 45, 7015-7025 (2011).

6. Zhu, T. et al. WMO/IGAC Impacts of Megacities on Air Pollution and Climate, World Meteorological Organization (WMO) Global Atmosphere Watch (GAW) Report No. 205 (2012).

7. NRC, National Research Council. Rethinking the Ozone Problem in Urban and Regional Air Pollution (The National Academies Press, Washington, 1991).

8. Wang, Y. et al. Sensitivity of surface ozone over China to 2000-2050 global changes of climate and emissions. Atmos. Environ. 75, 374-382 (2013).

9. WMO, Assessment for Decision-Makers, Scientific Assessment of Ozone Depletion: 2014, World Meteorological Organization and United Nations Environment Programme, WMO Global Ozone Research and Monitoring Project-Report No. 56 (Geneva, preprint for public release, 2014).

10. Bais, A. F. et al. Ozone depletion and climate change: impacts on UV radiation Photochem. Photobiol. Sci. 14, 19-52 (2015).

11. Liu, S. C. \& Trainer, M. Responses of the tropospheric ozone and odd hydrogen radicals to column ozone change. J. Atmos. Chem. 6, 221-233 (1988).

12. Thompson, A. M., Stewart, R. W., Owens, M. A. \& Herwehe, J. A. Sensitivity of tropospheric oxidants to global chemical and climate change. Atmos. Environ. 23 519-532 (1989)

13. Zhang, H., Wu, S., Huang, Y. \& Wang, Y. Effects of stratospheric ozone recovery on photochemistry and ozone air quality in the troposphere. Atmos. Chem. Phys. 14, 4079-4089 (2014).

14. Morgenstern, O. et al. Review of the global models used within phase 1 of the Chemistry-Climate Model Initiative (CCMI). Geosci. Model Dev. 10, 639-671 (2017).

15. McKinlay, A. F. \& Diffey, B. L. In Human Exposure to Ultraviolet Radiation: Risks and Regulations (eds Passchler, W. S. \& Bosnajokovic, B. F. M.) 83-86 (Elsevier, Amsterdam, 1987).

16. Knote, C. et al. Simulation of semi-explicit mechanisms of SOA formation from glyoxal in aerosol in a 3-D model. Atmos. Chem. Phys. 14, 6213-6239 (2014)

17. Madronich, S. \& Granier, C. Impact of recent total ozone changes on tropospheric ozone photodissociation, hydroxyl radicals, and methane trends. Geophys. Res. Lett. 19, 465-467 (1992).

18. Fuglestved, J. S., Jonson, J. E. \& Isaksen, I. S. A. Effects of reductions in stratospheric ozone on tropospheric chemistry through changes in photolysis rates. Tellus B Chem. Phys. Meteorol. 46, 172-192 (1994).

19. Granier, C. \& Shine, K. P. Chapter 10: Climate effects of ozone and haolcarbon changes, in Scientific Assessment of Ozone Depletion, 1998, WMO Global Ozone Research and Monitoring Project-Report 44 (Geneva, 1999).

20. McKenzie, R. L. et al. Ozone depletion and climate change: impacts on UV radiation. Photochem. Photobiol. Sci. 10, 182-198 (2011).

21. Michelsen, H. A., Salawitch, R. J., Wennberg, P. O. \& Anderson, J. G. Production of O(1D) from photolysis of O3. Geophys. Res. Lett. 21, 2227-2231 (1994).

22. Shetter, R. E. et al. Actinometric and radiometric measurement and modeling of the photolysis rate coefficient of ozone to O(1D) during Mauna Loa Observatory Photochemistry Experiment 2. J. Geophys. Res. 101, 14631-14641 (1996).

23. Mass, C. F., Ovens, D., Westrick, K. J. \& Colle, B. A. Does increasing horizontal resolution produce more skillful forecasts? Bull. Am. Meteorol. Soc. 83, 407-430 (2002).

24. Tie, X., Brasseur, G. \& Ying, Z. Impact of model resolution on chemical ozone formation in Mexico City: application of the WRF-Chem model.Atmos. Chem. Phys. 10, 8983-8995 (2010).

25. Zeng, G., Morgenstern, O., Braesicke, P. \& Pyle, J. A. Impact of stratospheric ozone recovery on tropospheric ozone and its budget. Geophys. Res. Lett. 37, L09805 (2010)
26. Guenther, A. et al. Estimates of global terrestrial isoprene emissions using MEGAN (Model of Emissions of Gases and Aerosols from Nature). Atmos. Chem. Phys. 6 3181-3210 (2006).

27. Harley, P., Deem, G., Flint, S. \& Caldwell, M. Effects of growth under elevated UV-B on photosynthesis and isoprene emission in Qurecus gambelii and Mucuna pruriens. Glob. Change Biol. 2, 149-154 (1996).

28. Tiiva, P. et al. Isoprene emission from a subarctic peatland under enhanced UV-B radiation. New Phytol. 176, 346-355 (2007).

29. Pallozzi, E. et al. BVOC emission from Populus $\times$ canadensis saplings in response to acute UV-A radiation. Physiol. Plant. 148, 51-61 (2013).

30. Tai, A. P. K., Val Martin, M. \& Heald, C. L. Threat to future global food security from climate change and ozone air pollution. Nat. Clim. Change 4, 817-821 (2014).

31. lacono, M. J. et al. Radiative forcing by long-lived greenhouse gases: calculations with the AER radiative transfer models. J. Geophys. Res. 113, D13103 (2008).

32. Janjic, Z. I. Nonsingular Implementation of the Mellor-Yamada Level 2.5 Scheme in the NCEP Meso Model. NCEP Office Note, No. 437, 61 (2002).

33. Barlage, $M$. et al. Noah land surface model modifications to improve snowpack prediction in the Colorado Rocky Mountains. J. Geophys. Res. 115, D22101 (2010).

34. Morrison, H., Thompson, G. \& Tatarskii, V. Impact of cloud microphysics on the development of trailing stratiform precipitation in a simulated squall line: comparison of one-and two-moment schemes. Mon. Weather Rev. 137, 991-1007 (2009).

35. Grell, G. A. \& Freitas, S. R. A scale and aerosol aware stochastic convective parameterization for weather and air quality modeling. Atmos. Chem. Phys. 14 5233-5450 (2014).

36. Im, U. et al. Evaluation of operational online-coupled regional air quality models over Europe and North America in the context of AQMEll phase 2. Part I: Ozone. Atmos. Environ. 115, 404-420 (2015).

37. Canty, T. P. et al. Ozone and NOx chemistry in the eastern US: evaluation of CMAQ/CB05 with satellite (OMI) data. Atmos. Chem. Phys. 15, 10925-10982 (2015).

38. Ryu, Y. - H., Hodzic, A., Barre, J., Descombes, G. \& Minnis, P. Quantifying errors in surface ozone predictions associated with clouds over CONUS: a WRF-Chem modeling study using satellite cloud retrievals. Atmos. Chem. Phys. 18, 7509-7525 (2018).

39. Travis, K. R. et al. Why do models overestimate surface ozone in the Southeast United States?. Atmos. Chem. Phys. 16, 13561-13577 (2016).

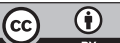

Open Access This article is licensed under a Creative Commons Attribution 4.0 International License, which permits use, sharing, adaptation, distribution and reproduction in any medium or format, as long as you give appropriate credit to the original author(s) and the source, provide a link to the Creative Commons license, and indicate if changes were made. The images or other third party material in this article are included in the article's Creative Commons license, unless indicated otherwise in a credit line to the material. If material is not included in the article's Creative Commons license and your intended use is not permitted by statutory regulation or exceeds the permitted use, you will need to obtain permission directly from the copyright holder. To view a copy of this license, visit http://creativecommons. org/licenses/by/4.0/.

(c) The Author(s) 2018 